\title{
INTRODUCTORY NOTES ON "AFRICANA PHILOSOPHY" AND LEWIS GORDON'S POSTCOLONIAL HUMANISM ${ }^{1}$
}

\author{
NOTAS INTRODUTÓRIAS SOBRE "FILOSOFIA AFRICANA" E O \\ HUMANISMO PÓS-COLONIAL DE LEWIS GORDON
}

\author{
DOI: $\underline{\text { https://doi.org/10.20873/uft.2179-3948.2018v9n1p46 }}$
}

\author{
Deivison Mendes Faustino ${ }^{2}$
}

\begin{abstract}
Can humanism be post-colonial? What is Africana Philosophy? Who is Lewis Gordon? This paper presents some typical elements of the Jamaican philosopher Lewis Gordon's thought and relates it to the field of Africana Philosophy. For this purpose, it seeks to delineate its theoretical influences and the usage of concepts, such as theodicy, bad faith and reason to understand anti-black racism. In this sense, the following argument pivots on Lewis Gordon's singular contribution to different areas of study, especially political philosophy, social sciences and the humanities.
\end{abstract}

Keywords: Lewis Gordon; Africana Philosophy; Post-colonial Humanism; Existential Phenomenology.

Resumo: O humanismo pode ser pós-colonial? O que é a Filosofia Africana? Quem é Lewis Gordon? Este artigo apresenta alguns elementos típicos do pensamento do filósofo jamaicano Lewis Gordon e relaciona-o ao campo da Filosofia Africana. Para tanto, procura delinear suas influências teóricas e o uso de conceitos, como a teodiceia, a má-fé e a razão para entender o racismo anti-negro. Nesse sentido, argumenta-se em torno da contribuição singular de Lewis Gordon para diferentes áreas de estudo, especialmente filosofia política, ciências sociais e humanidades.

Palavras-chave: Lewis Gordon; Filosofia Africana; Humanismo Pós-colonial; Fenomenologia Existencial.

${ }^{1}$ I especially thank Professors Dr. Marcos Silva and Silva and Wanderson Flor do Nascimento for the precious remarks offered, and Fernanda Sousa for the careful review.

${ }^{2}$ Federal University of São Paulo - UNIFESP. Email: sdeivison@ @otmail.com 


\section{Introduction: "Sometimes a gun is a gun"}

This chapter title, which could be translated as "Sometimes, a gun is (just) a gun", is appropriate enough to introduce the presentation of Afro-Jewish Jamaican philosopher, political thinker, educator and musician, Lewis Ricardo Gordon. The above-referenced title, excerpted from his last book What Fanon said (2015), refers to Frantz Fanon's critique of the book Psychologie de la colonization, from Lacanian psychologist Dominique Octave Mannoni (1950), when he reduces the real world to the possible meanings one may infer from it. Observing that Malagasies often had dreams of black bulls or armed Senegalese soldiers terrorizing them, Mannomi concluded these "phallic" nightmares were due to a psychic complex of inferiority, already existent among Madagascar island inhabitants before French colonization, which explained, therefore, a Malagasy colonial vocation. ${ }^{3}$.

In response, Fanon dedicates an entire chapter to Mannomi, arguing that meanings should not be seen as explainable in themselves, but through concrete analyses of reality; in the Malagasy case, the systematic use of Senegalese soldiers by French colonial occupation forces in Madagascar Island. As Fanon explains while commenting on the related dreams:

The enraged black bull is not the phallus. The two black men are not the two father figures - the one standing for the real father, the other for the primal ancestor. Here is what a thorough analysis could have found, on the same basis of M. Mannoni's conclusions in his section, 'The Cult of the Dead and the Family.' The rifle of the Senegalese soldier is not a penis but a genuine rifle, model Lebel 1916. The black bull and the robber are not lolos_- "reincarnated souls"-but actually the irruption of real fantasies into sleep (FANON, 2008:100).

Lewis Gordon's philosophical production arises in the wake of such a tradition, but, at the same time, it seeks its revision due to contemporary challenges of epistemic racism's perpetuation. This philosopher, born in Jamaica Island and raised in the Bronx, New York, has even played jazz in nightclubs before graduating with a degree in philosophy and political

\footnotetext{
${ }^{3}$ This "Prospero complex", reveals a latent feelings of inferiority and a desire for a (White) father to assume the place of the law. Citing Mannoni, Fanon claims that: "the 'Prospero complex' (is) defined as the sum of those unconscious neurotic tendencies that delineate at the same time the "picture" of the paternalist colonial and the portrait of 'the racialist whose daughter has suffered an [imaginary] attempted rape at the hands of an inferior being.' Prospero, as we know, is the main character of Shakespeare's comedy, The Tempest. Opposite him we have his daughter, Miranda, and Caliban. Toward Caliban, Prospero assumes an attitude that is well known to Americans in the southern United States. Are they not forever saying that the niggers are just waiting for the chance to jump on white women?" (FANON, 2008, p. 80)
} 
science and being inducted into the Phi Beta Kappa Honor Society. He also obtained a doctorate in philosophy from Yale University, advised by Maurice Natanson, a phenomenologist and follower of Alfred Schütz.

In Gordon's writings, phenomenology - especially from Husserl's matrix - merges with critical race theory, existentialist sociology and the thought of Marx, Du Bois and Fanon, to compose what Nissim-Sabat calls "new postcolonial humanism" (NISSIM-SABAT, 2011 include page). Therefore, Gordon seeks to correlate concrete as well as (inter)subjective aspects of social reality. Husserl's influence is noticeable, since he frames phenomenology as investigatory method for contemporary reality. In Gordon's view:

\begin{abstract}
Phenomenological appeals have the distinct advantage of recognizing intentional dimensions to human phenomena. They entail an appeal to the intersubjective foundations of meaning, to their constitutive features manifested in the realm of sociality. Moreover, like the textual appeals, phenomenological one's afford a space for openness by suspending ontological commitments to the phenomena beyond their status as phenomena. (GORDON qtd. in NISSIM-SABAT, 2011, p. 43)
\end{abstract}

Thus, the existential phenomenology proposed by Gordon allows for thinking about Sciences of the Spirit (Geisteswissenschaft) as a negotiation between existential interactions of individuals, people, and, in a more thorough picture, the trajectory of human community, without, nevertheless, taking this wholeness as fixed and/or aprioristic entities (NISSIMSABAT, 2011, p. 35). This means, as Nissim-Sabat argues, that Lewis Gordon's phenomenology represents a commitment that is, at the same time, humanist, due to its radical concerns with post-colonial human emancipation and its refusal of racism and identity essentialisms. As we will see, it is from such a perspective that the philosopher presents antiblack racism as well as black identity itself as self-deceptive expressions.

\title{
1 But what is Africana Philosophy?
}

Lewis Gordon establishes his discursive position from a thought tradition he calls Africana philosophy. It is well known that, in English, the nationality of someone from Africa is African and not Africana. In the US academy, for example, there are African studies, focusing on the study of African history and culture, and Black studies or African-American studies, focusing on the comprehension of black people's reality in the United States. However, the 
term Africana has a broader scope, since it encompasses, at once, studies about African people and their diaspora. Nonetheless, this field of study transcends the ostensible character of the field, for it presents itself as a transdisciplinary theoretical perspective committed to overcoming multiple manifestations of racism. To Gordon $(2000,2008)$, the roots of Africana self-reflection ${ }^{4}$ are in Africa, but that philosophical positioning is not oriented by acknowledging or discovering an original identity that, supposedly, already existed before colonization, but by a collective identity assumedly posterior and in counterpoint to colonial sociability processes and products.

The philosophical viability of such self-reflection, as argues the Jamaican philosopher, demands over coming western binarisms, such as past/present, reason/emotion, traditional/modern and, above all, thinking about the influence of past over present so that there are possibilities of reinterpreting this past from the perspective of present-time issues. From this prism, he faces the one and multiple issue stemming from Africana identity. In the past the African ancestors did not see themselves as "African" - just as Ionian and Spartan people did not see themselves as European - the term would only make sense from present resignifications ${ }^{5}$, which would allow him to talk about Africana Philosophy, so much as in European or Asian philosophy (GORDON, 2008)

That said, Gordon argues that the main challenge Africana Philosophy faces is overcoming the racialization of "love for wisdom," that is to say, its representation as essentially white/European (Ibid). Traditionally, and at present, professors teach students that philosophy was born in Greece and human reason developed more fully in Europe than in any part of the world. (MORE, 1996).Counterpointing this idea, the Jamaican philosopher relies on the works of Théophile Obenga (1992), Enrique Dussel (2000) and Martin Bernal (1987; 2001) to state that the term philosophy (Greek philia $=$ fraternal love and sofia $=$ wisdom) came from

\footnotetext{
${ }^{4}$ According to Husserl, "Phenomenology becomes 'prime Philosophy' by radical self-reflection, and also universal, because of that. On a plainly reflexive attitude, the philosopher observes 'things' in their original immediate and pure state, letting himself be guided exclusively by them. In such evincement attitude, he is able to describe what is immediately given to conscience. (ZILLES, 2012: 23, my emphasis)

${ }^{5}$ This position held by Gordon seems to be different than a more nativist view, such as the one adopted by Cheikh Anta Diop (2014), Magobo More (1996) and Eduardo David Oliveira (2003), as well as a view more critical of identity essentialisms, as in Kwama Anthony Appiah (1992).
} 
KMT (Egypt $)^{6}$ and that Greek philosophy itself could only develop as such from its exchange of knowledge with civilizations around it ${ }^{7}$.

Therefore, to Gordon (1995a; 2008), the idea of an ancient Greek creator of philosophy

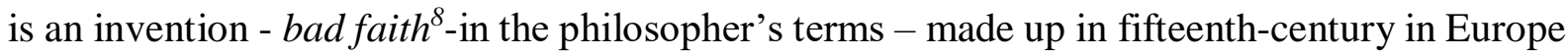
during the Renaissance. This is a moment in which European Man discovered himself as a subject of history, beginning to represent himself as the core and measure of each and every entity. Before that, warns Gordon, India was considered the center of the world and Europe was only its West (Ibid),. However, the race to India, the Christian Reconqueston the Iberian Peninsula after Moorish dominion, Christopher Columbus's arrival in Bahamas, as well as the very development of productive forces in Europe, which contributed to the rise of"new" focus on Europe as a specific geopolitical and historic territory and as its intellectual center (GORDON, 2008, p. 05, insert page; ROBINSON, 2001, p. 33). If White is presented as universal human expression, Black may only be the other pole: distance and/or a threat to this (pseudo) universal humanity.

For this reason, Gordon contends that Africana philosophy's developmental pattern is better viewed in the context of colonization, or, in other words, as a counterpoint to it. However, in the eighteenth and nineteenth centuries, figures such as Olaudah Equiano (1745 - 1797), Ottobah Cugoano (1757 - 1791), Frederick Douglass (1818 - 1895), Harriet Jacobs (1813 1897), Mary Prince (1788 - 1899) and David Walker (1796 - 1830), made themselves heard

\footnotetext{
${ }^{6}$ Molefe Asante presents this question as follows: "literally, Philosophy 'would be' a Greek word, from 'Philo', which means brother or lover; and 'Sophia', that means wisdom or wise. Therefore, a philosopher is called "a friend of wisdom". Nevertheless, the origin of the term - 'Sophia' - clearly comes from an African language (MduNtr), that was ancient Egypt language, where the word "Seba", that means 'wise', figures, for the first time, in $2052 \mathrm{BC}$, in the tomb of Antef I (that is, much before the existence of Greece or Greek). So the word became 'Sebo' in Coptic, and 'Sophia' in Greek. In the term Philosophy - the lover of wisdom - there is precisely 'Seba', that is the same as 'wise', as provable from writings found in very old Egyptian tombs".(ASANTE, 2015)

${ }^{7}$ About the relation of philosophical exchange between Africa and Europe, see also "Afrique en dialogue, Afrique en auto-questionnement: universalisme ou provincialisme? Compromis d'Atlantou initiative historique?", from Nkolo Foe (2013).

${ }^{8}$ Relatively distinct from the common sense meaning of "bad faith", interpreting it as a lie told on purpose to others. Sartre specifies that, "The situation cannot be the same for bad faith if this, as we have said, is indeed a lie to oneself. To be sure, the one who practices bad faith is hiding a displeasing truth or presenting as truth a pleasing untruth. Bad faith then has in appearance the structure of falsehood. Only what changes everything is the fact that in bad faith it is from myself that I am hiding the truth" (SARTRE, 1953)
} 
by presenting political and theoretical challenges to such negation of black humanity and assuming an Africana perspective. In the twentieth century, according to Gordon, this task was taken up by activist intellectuals like Marcus Garvey (1887 - 1940), Ida B. Wells (1862 - 1931), W. E. B. DuBois (1868 - 1963), Alain Locke (1885 - 1954), Frantz Fanon (1925 - 1961), Wilson Harris (1921 - ) Sylvia Wynter (1928 - ), among others, whose voices still echo in contemporary anti-racist literature.

In his An Introduction to Africana Philosophy (2008), Gordon lists hundreds of thinkers whose works may be framed in this field or from this perspective. Yet, still evident is the absence of important Afro-diasporic thinkers located in South America, or even lesser known African from the Hispanophone and Lusophone universe - such as MicaelaBastidasPuyucahua (1745 - 1781), José Manuel Valdez (1767 - 1843), Luiz Gama (1830 - 1882), Machado de Assis (1839 - 1908), Guerreiro Ramos (1915 - 1982), Abdias do Nascimento (1914 - 2011), Lélia Gonzalez (1935 - 1994), Victoria Santa Cruz (1922 - 2014), VirgíniaBicudo (1919 2003), Amilcar Cabral (1924 - 1973), Mario Pinto de Andrade (1928 - 1990) and others. The purpose of his selection is to ascertain that the elements that reflect this perspective were already present centuries before the term Africana was formulated.

The other side of Africana, or Gordonian, self-reflection is that, if racism - especially anti-black racism - is a western expression of $b a d f a i t h h^{9}$, cultural, political and theoretical movements that oppose it would be at risk of incurring self-deceit. Just like Frantz Fanon, the author acknowledges the capital importance of various movements towards the affirmation of undervalued identities. But Gordon is aware of the risks that their repetition - even conversely and in a subversive political way - present an escape from themselves - from their responsibility with their own freedom - that characterizes bad faith.

Gordon (1995a, 1995b, 1997), in frank dialogue with Sartre, views "absolute freedom", as subject structural indetermination; the enforceability of choosing and having to face the consequences of his/her own choices and the insurmountable contingency of the world to create

\footnotetext{
${ }^{9}$ Bad Faith works for the benefit of White supremacy as a form of self-deceit that allows for the self-assurance of Europeans and their descendants - but also solidifies the assumptions of capital civilization - as unquestionably sovereign.
} 
an almost unbearable anguish - nausea. ${ }^{10}$ To escape from this reality - this obligation of choosing - and redress such anguish on the surface, we create a kind of enclosed ego that deludes us into assuming some role: father, doctor, philosopher or other identities. For Sartre, Fanon and Gordon, bad faith is a symbolic escape of an unpleasant reality through a projection that alleviates existence. The specifically Africana concern for Gordon is that black identity, even in its radical uncovering of anti-black bad faith, does not escape the traps of self-deceit. Therefore, to Gordon, Black does not exist - in itself - unless it projects an ego that seeks protection from anti-black attacks. The problem turns up when it is forgotten and this identity projection is taken as ontologically true (HENRY, 2006, p. 16).

The Antiguan-born philosopher Paget Henry, systematizes the development of the phenomenological tradition in Africana Philosophyby suggesting the existence of three important "chapters"11. The first, "written" by the African American sociologist, historian, and philosopher of existence W.E.B. Du Bois, consists of a black revision of Hegelian dialectics through the metaphor of Lord and Bondsman to illustrate the challenges of double consciousness in a racist society. However, instead of Hegel, who thinks of wholeness as a synonym for Europe, or Europe as expression of universality, Du Bois thinks of these categories

\footnotetext{
${ }^{10}$ Different from Fanon, for whom "nausea" is the bad feeling of not being recognized, in Gordon it comes closer to the Sartrean idea of the anguish of a self-reflexive subject facing the absolute contingency of existence.It occurs that such phenomena, for both, the tense relations between "Self" and the "other" pass through an objectification of perspective that converts another's "for itself" into an "in itself” for, the "Self" resulting, not rarely, in violence from such objectification.

${ }^{11}$ Gordon himself, while recounting this trajectory, includes the African American feminist thinker Anna Julia Cooper $(1858-1964)$ as a pioneer of this phenomenological approach. The daughter of a slave who married the "lord", she had access, in the nineteenth century, to basic schooling and university, having become a teacher. She got her PhD in Comparative Literature, at the Sorbonne, with a thesis about Haitian Revolution entitled L'Attitude de la France a l'égard de l'esclavage pendant la Révolution. Cooper was also one of the organizers of the fist Pan-African Congress, in 1901, in London, and one of the pioneers of what is now referred to as black feminist thought. Her theoretical productions question meritocracy in education, starting from a reflection on the places and opportunities available to black men and women, as well as their impact on the educational performance of individuals. Gordon sums up Cooper's argument as follows: "The antiblack racist argument is that the absence of black contribution to civilization suggests that humankind could do well without people. Cooper's response was that worth was a function of what an individual produced in relation to that which was invested in him or her. She pointed out that very little was invested in blacks, and even less in black women. Yet what blacks have produced is enormous. There is not only the slave labor used to build much of the Americas, but also the innovations and strides of black communities under enormously handicapped conditions" (2008, p. 71).
} 
as globally complementary, encompassing other non-European sociabilities and, in so doing, breaks with Hegel (Ibid.).

Africana Philosophy's second chapter - to Henry and the third, to Gordon - may be productions of Caribbean Psychiatrist Frantz Fanon(Ibid.), pointing out that ontogeny, as philosophical self-reflection directed inwards to the subject, must be completed by sociogeny: perception of the influence of economic and social realities on individual choices. In Fanon's words:

\begin{abstract}
Before beginning the case, I have to say certain things. The analysis that I am undertaking is psychological. In spite of this it is apparent to me that the effective disalienation of the black man entails an immediate recognition of social and economic realities. If there is an inferiority complex, it is the outcome of a double process:

—primarily, economic;

— subsequently, the internalization —or, better, the epidermalization - of this inferiority.

Reacting against the constitutionalist tendency of the late nineteenth century, Freud insisted that the individual factor be taken into account through psychoanalysis. $\mathrm{He}$ substituted for a phylogenetic theory the ontogenetic perspective. It will be seen that the black man's alienation is not an individual question.

Beside phylogeny and ontogeny stands sociogeny. In one sense, conforming to the view of Leconte and Damey, let us say that this is a question of a sociodiagnostic.

What is the prognosis? But society, unlike biochemical processes, cannot escape human influences. Man is what brings society into being. (FANON, 2008, p. 4)
\end{abstract}

Henry (2006) and Gordon (2008) agree that accepting ontogenyas incompleteness does not mean its withdrawal, but a clamor for its complement to other dimensions of our existence. Fanon's main contribution, in their view, is pointing that Africana conscience and selfconstituent powers must be dialectically completed and verified by formative powers of sociocultural orders. More importantly, both philosophers hold that Africana people's desalination, about which Fanon speaks, would propose implosion not only of anti-black racism, but also, and above all, the caricatures created by it, making the subjects face their real existential indetermination, what Fanon defined as zone of non-being. ${ }^{12}$ (GORDON, 2005, p. $3)$.

\footnotetext{
${ }^{12}$ In Black Skin, White Masks, we find two distinct features of the expression "non-being." The first one, implicit throughout the text, supposes the denial of black people's humanity, for the Being, as entity, is always white, and the black, in binary opposition, is the non-being. However, there is a second feature, with a phenomenological
} 
Furthermore, Lewis Gordon (2008) enumerates a series of other Fanonian contributions to Africana Philosophy. Among them, the development of an anticolonial philosophy that is, at the same time, a questioning of colonialism, philosophy and reason. For him it is even ironic to present Fanon as a contributor tophilosophy - since philosophy is the reign of reason - as he himself had already warned that reason always found a way of taking off when he entered the room. Nevertheless, we will see that Fanon's philosophical position is understood by Gordon as a "teleological suspension of Philosophy"13 (2008: 82), because it does not present acounter point to reason, but at least removes it from its pedestal, releasing it from its absolutizing and instrumental fetishes. Therefore, Fanonian philosophy, to Gordon, points to the Kierkegaardian worry about transcending philosophy's own deontological biases.

This lenghty description of the Fanonian approach is important to this paper's focus, because it decisively marks Lewis Gordon's thought, even though it is possible to identify some

slant, that just assumes the prior existential vagueness that, it believes, characterizes human being, which is the "zone of non-being". Fanon declares: "There is a zone of non-being, an extraordinary sterile and arid region, where black is not a man, and mankind is digging into its own flesh to find meaning. Most black people do not enjoy the benefit of performing this descentto true Hell" (FANON, 2008, p. 158).

\footnotetext{
${ }^{13}$ The term "teleological suspension” addresses the Danish philosopher Søren Aabye Kierkegaard (1813-1855), in his search to problematize ethics limits. In Fear and Trembling, under the pseudonym of Johannes de Silentio, Kierkegaard takes back the biblical metaphor of Abraham in his intent to "sacrifice" his beloved child Isaac, obeying divine orders. Following God's orders, Abraham goes against human ethics that urges parents to love and protect their children more than themselves. If he did otherwise, however, Abraham would be questioning God's orders, which are above any human comprehension. As is well known, in this mythology, the parent proves his unrestrained faith by preparing the murder that does not consummate only because an angel, God's messenger, keeps him from doing it. Analyzing Abraham's case and stating that "his pain is his safety" (1979:275), Kierkegaard suggests that, differently from tragic Heroes - referring to classical tragedies - Who kill on behalf of the collective, the nation and ethics, the absurd - the faith - fact that Abraham lives marks him asan individual who transcends ethics, in obeisance of something above the collective, stepping out, in this way, from the finite towards infinite - the absolute.The interesting point for Gordon here is that philosophy, just like ethics, are parameters of world comprehension, with strains imposed by human history and geography and, thus, both cannot be thought as absolute entities. There are moments when the act of knowing demands a "teleological suspension" of philosophy, as he states: "By that, I mean that the kind of reason Fanon was fighting against led its practitioners to believe in its absoluteness. When Philosophy becomes absolute or "deontological," it loses its own sense of purpose and becomes, like the universal in Søren Kierkegaard's Fear and Trembling, below the realm of faith. Since an absolute is higher than a universal, that form of reasoning collapses upon itself by attempting to become greater than itself. However, such an attempt would be teleological, and in Kierkegaard's case, the teleological movement involves reaching out to God. Ironically, such reaching out brings one back to the ethical, since God is not evil, and in this sense, one has ironically become more ethical by being willing to transcend ethics for its own sake. Fanon understood that philosophy could best be salvaged by our willingness to transcend it" (GORDON, 2008: 82).
} 
important differences between them. In this regard, Paget Henry (2006) argues that the authors come closer to Sartre's influence, visible in the effort to philosophically approach ego and conscience, but they are different since the psychoanalyst Fanon focuses on the ego, while the professional philosopher Gordon, focuses on conscience and, in so doing, offers a larger systematization of Africana phenomenological philosophical bases. Thereafter, continues Henry, Fanon defines human reality as an ego wish, that is to say, a need towards the world, while Gordon defines human reality as freedom, with no a priori law, neither desire, as Fanon suggests, would determine this.

Therefore, to Henry, Gordon's originality - whom he conceives as the third cornerstone of Africana Philosophy - offers a larger systematization of that tradition and in the phenomenological analysis of the "state of being black" in the "post-colonial age"14.

\section{Theodicy}

One of Gordon's most interesting contributions to contemporary philosophy lies in his operationalization of the old notion of "theodicy" which he names theodicean rationalizations. The term theodicy has its origins in Greek "theós" $(\theta \varepsilon o ́ \varsigma=G o d)$ and "dike"e" ( $\delta i \kappa \eta=$ Justice), which means, literally, “God's justice”. Theodicean rationalizations, to Gordon (2008, 2014, 2015), reach their apex in the answers of the African philosopher Augustine of Hipona. ${ }^{15}$ The

\footnotetext{
${ }^{14}$ In this passage, the author uses the termspost-colonial and post-segregation era in a temporal sense, as a synonym of post-independencies period. See Henry (2006: 15)

${ }^{15}$ Hippo (latin Hippo Regius), where Augustine of Hippo (Saint Augustine) was born, was the name of present Annaba city, in Algeria. The son of a Roman father (Patricius) and Berber mother (Monica), Augustine had never left the African continent. What is relevant to Gordon is the extent that, in his view, the West itself can't be explained if not by the relation it establishes with that which was conveyed as external to it: "[...] some thoughts on St. Augustine's African location should strengthen the critique of not-out-of- Africa theses, which is a subtext of this book in general and chapter in particular. St. Aurelius Augustine was the son of a Roman father (Patricius) and a Berber mother (Monica). By now the reader should notice that "Berber" people are usually evoked in the north African context as a way of referring to Africa without outright saying black Africa. The term often refers to almost any indigenous, nomadic group of Africans who happen to be in north Africa. The Berbers of today do not necessarily look like the Berbers of nearly two millennia ago, and as our discussion in our introduction showed, it is an error to look at the people of any region as morphologically and culturally static and homogeneous when the region has been undergoing conquest and colonization for thousands of years. In the case of north Africa the populations have been affected by waves of European and West Asian conquest and colonization in antiquity by Phoenicians, Greeks, and Romans, a Visigoth and then Islamic Arabic onslaught in the Middle Ages, and then, in modern times since the defeat of the Moors in Iberia Peninsula in 1492, the Spanish, French, and Italians. St. Augustine is exclusively Roman Christian only through a logic that denies mixture, where he supposedly cannot
} 
famous Saint Augustine presents the following trilemma of evil ${ }^{16}$, known as the Paradox of Epicure: If God is omniscient, omnipotent and benevolent, why, then, does he not end the evil of the world? If He does not, it is because He cannot. Even wishing for its end, He is not omnipotent. If He does not do it, it is because he does not know about its existence, thus $\mathrm{He}$ is not omniscient. If He knows, in His omniscience and could end it in His omnipotence, but still does not do so, He is not benevolent. The justification for God's existence, before the issue of evil, is, therefore, theodicy.

The paradox above intensifies when the Judeo-Christian motto - that is, the idea that $\mathrm{He}$ is in everything that exists - adds to it. If it is so and still true that evil exists, would He also be there, in that which stands in opposition to goodness? Would evil be part of God or God part of evil, once He is in everything? The theodicy of St. Augustine is an exemplar:

And I enquired what iniquity should be:but I found it not to be a substance, but a serving merely of the will crooked quite away from thee, O God (who art the supreme substance) towards these lower things, casting away its inward parts and and puffed up outwardly.(AUGUSTINE, book seven, chap. XVI, 1912)

According to St. Augustine, the answer to the Paradox of Epicure would be in the fact that God did not create evil, neither the former nor the latter composes the divine system which consists in unstrained goodness. Instead, it resides on a (free) will that corrupts itself by choosing to step away from Him. In other words, to Augustine, "evil occurs when somebody takes actions that take them away from God, away from goodness - that is, towards destruction" (KIESPELL, 2014). This is the issue of interest to Lewis Gordon (2008) for explaining modern western theodicy: if God is infinitely good and perfect, evil and corruption are only recognizable - when so they are - as a threat to or a distancing from Him, something outside God, never part of Him. So, western theodicean rationalization works as an ideological mechanism of self-deceit - which Gordon (1995a, 1997) labels as bad faith - that falsely

be Roman and Berber, a product of two sides of the Mediterranean. Nearly all of the philosophers we have examined are products of more than one civilization and more than one kind of people"(GORDON, 2008: 188-9). ${ }^{16}$ It consists in a difficult choice among three options, any of them apparently unacceptable or unfavorable to the other. 
transfers all the system's contradictions, such as evil, corruption, violence, rapine, outwards presenting itself as perfect and these features as aberrations.

Gordon (2008) insists that, with theodicy's secularization, argument legitimation starts becomes full filled through other political systems, like modern science and the forms of rationalization it offers. Such a grammar of rationalization and legitimation, constituent of a secularized theodicy, was the centerpiece, not only of European absolute State, but also of colonization itself.

\begin{abstract}
The formation of such systems and their theodicean rationalizations leads to the construction of insiders and outsiders. The "outside" is an invisible reality generated, in its invisibility, as nonexistent. The effect, then, is that a new link with theodicy emerges and the result is the rationalization of people who are inherently justified versus those who are not necessarily people and thus could never be justified under the principles of the systems that form both. The result is, as Du Bois famously observed, the splitting of worlds and consciousness itself according to the norms of US society and its contradictions (GORDON, 2008, p. 77)
\end{abstract}

In the rise of modern society, when the idea of human being as a measure of everything (theodicy), that is, the self built by reason, the black and many Others expelled from western theodicy, are not only distant, but also and above all tension and threaten such (pseudo) humanity, therefore they need to be watched, punished, trained or even exterminated. However, it is not only a question of banning them from western "paradise" by creating an ontological separation between the Euro-American "us" and "them" from the Global South, but mainly by imposing on "them" all those contradictions that are also "ours", dispensing the Euro-American us from any and all responsibility for what only exists due to their own choices.

The Sartrean concept of bad faith is also used to explain the divination of the White world. ${ }^{17}$ Gordon uses the works of Mignolo (2003), Robinson (2001) and Dussel (2003) to argue that racism had its genesis in the early modern age, through Indigenous genocide and African slavery, in addition to the spreading of stereo types about slaves as decayed beings or

\footnotetext{
${ }^{17}$ In his Bad Faith and Anti-black Racism, Gordon states: "Examining racism from the standpoint of Sartrean philosophy of existence isn't a new idea. Jean-Paul Sartre has explored racial concerns in some of his work from the 1940s, and early 1950s, such as Anti-Semite and Jew, Notebooks for Ethics, The Respectful Prostitute, Black Orpheus, and Black Presence. The virtues and vices of Anti-Semite and Jews have received study, but anti-black racism from the standpoint of bad faith has received relatively cursory and quite inadequate attention" (GORDON, 1995, p. 3).
} 
non-beings. This view was useful for modern capitalist consolidation, to the extent that it created and spread the fantasy that colonial power had no limits. Since then, capitalist expansion has been inextricable to the slaughter and negation of the other. In this sense, bad faith has become the modus operandi of the capitalist conscience (NISSIM-SABAT, 2011).

Therefore in western theodicy, the White/European/Western subject that he dismissed his own contradictions. He/she has acquired sacred status, playing the role of the incarnation of goodness, beauty and absolute truth and presenting him/herself as the standard of reality, humanity and universality. The Black, in his turn, when presented, plays the role of disgraced opposition, never conceived as human. Because of this, philosophy, science and social thought produced by blacks need not be considered thought per se. If what expresses humanity, in Europe, is reason, and the black is not human, he could not be considered a knowledge producer. Hence, Gordon's outrage is justified when Hannah Arendt (1969) criticizes Fanon's The Wretched of the Earth, derogatorily naming Fanon as apologist of violence. Gordon (2014, 2015) considers that Arend thad not even read the book, but only criticized it based on the preface, written by the white philosopher Jean-Paul Sartre:

\begin{abstract}
Arendt's racism turned up in her criticism in On Violence. In fact she spent more time with Sartre than Fanon. Why? Indeed, she considered the white man as the place of genuine thought. If she had read Fanon, she would have realized they had much more in common. For example, both believed in politics, in distinction between will in general and general will (in Rousseau's way), in distinction between force and legitimate violence, in the issue of human dignity and much more. However, her eurocentrism prevailed. Moreover, which is worse, she had such a racism that she could see herself more worried about Boers becoming similar to South African native population than about the fact they were colonizing ${ }^{18}$ (GORDON, 2014).
\end{abstract}

Nevertheless, in this bad faith movement that sees White as a coherent entity, Black will not be the only one alienated from his humanity, but the White himself - or even western thought - only presents itself by hiding one part of itself - the one it can only see in the Other. Thus, its relation with this logic is based on a constant meeting with a false universal. Gordon

\footnotetext{
${ }^{18}$ In the following excerpt, Gordon (2014) has harsh words for the author: "Arendt simply lacked the ability to see European civilization bearers as violent, even in the wake of Holocaust. Fanon, however, was among those soldiers who freed the ungrateful prisoners from the concentration fields (ungrateful bexause they would have preferred, in some cases, to be freed by white people), among those who were working in solidarity with the Arabs who hated blacks, working through struggles even against domestic abuses (a subject I discuss in my book What Fanon Said): he looked to the core of violence issue as a peculiarly social transformation of force and brutality".
} 
(2006, 2008) states that it means the black world links itself to the truth more than the white world, because its perceptual domain, over which allegations of truth may recur, is much wider than the white world, as (false) universal, is able to admit.

Lewis Gordon (2014) argues that theodicean rationalization is not limited to political identities, dwelling on the very modern notions of philosophy and science, when these are seen as absolute. Furthermore, according to him, one of Frantz Fanon's and W.E.B Du Bois' main contributions was the "teleological suspension of Philosophy". ${ }^{19}$ The same criticisms, of philosophy - as well as reason in general and science in particular -can be extended to the classic theorists of the social sciences, widely referenced by Gordon, such as Marx, Sartre, Husserl, Heidegger, Habermas, Foucault, and Derrida, among others. When certain theories or theorists are cited by critics, we act as if they are omniscient deities: "therefore, racism, sexism, homophobia, classism and all forms of humanity degradation we read in the texts become just a failure in how we read them" (GORDON, Ibid.).

However, warns Gordon, critics of classical theodicy is not a call for not reading them, but for doing it considering their contribution and limits.

[...] It is a mistake to infer that by pointing to the fact that these are elements in texts written by human beings is a call not to read them. I sustain that it is false. Denouncing theodicy in texts means rejecting such an approach. It is a call to really reading the texts. This means bringing to the foreground the humanness of the authors. It means admitting they are not perfect texts, but have human imperfections.(GORDON, 2014).

\section{Reason, modern age and colonialism}

According to Lewis Gordon (1995b, 2008, 2014, 2015), Frantz Fanon's writings were guided by the challenge of freedom and restrictions imposed on it in modern world. On this discursive route, the issue of reason, and constant efforts to take it as an absolute entity, is faced. Due to Husserl's (1982) and Kierkegaard's (1983) influence, the western usage of reason is

\footnotetext{
${ }^{19}$ See note 14.
} 
often considered as self-deceit. Gordon, in his turn, states that when reason - or philosophy becomes absolute, it loses its own purpose.

Colonization of reason is aspiration to instrumental rationality. The idea is that reason does not always "behave well". As which also evaluates rationality, a question comes up: Is reason rational? Reason, I sustain, as something that evaluates even itself, must go beyond itself and, therefore, is not ultimately consistent. The effort to reach supreme rationality engenders colonization of reason. However, as we know, "it" continues to be challenging (GORDON, 2014).

Yet the problem posed by Fanon, as Gordon argues, is even graver. Firstly, as seen before, western theodicy consists in reducing humanity to reason and, after that, in naming the European - or the White - as the universal expression of humanity. Therefore, White is seen as inherently rational and Black, its opposite, that is, an irrational animal. However, reason already strained by colonial alienation - is often used in favor of white supremacy. In $L$ 'an $V$ de la Révolution Algérienne (1959), Fanon offers many examples of how colonialism drew upon reason to impose its domain over people considered irrational. Briefly, in colonialism, not only is God presented as a white man, but reason itself (deified) operates as witness to the superiority of some over others.

There is, in this colonial movement, sort of a geographical centering of reason, that is expressed in its reduction to western historical manifestations and by the (pseudo) universalization of European subject as well, which begins to figure as universal expression of humanness (HENRY, 2006). Gordon (2006) contends that even European phenomenology - in which Descartes, Kant, Hegel and Husserl are remarkable -I critiques different forms of selfdeceit that ended up reproducing a self-reflexive practice that presents the latent movements of a universal reason inside the core of European subject. Nonetheless, for him, modern racism and Eurocentrism born from that are not expressions of reason, but of its eclipse instead.

For I am not so much anti-modern as I am anti Eurocentrism. There are elements of modernity that I avow and elements that I reject. To reject Eurocentrism is not identical to rejecting European civilization in toto or rejecting modernity, and it is a seriously racist form of reasoning that would make white people the only bearers of a modern consciousness. One would have to conclude, in effect, that black people are incapable of being modern or developing their own forms of modernity or alternatives beyond pre-modernity, modernity (GORDON, 1997, p. 102). 
In this sense, he maintains that the paradox Fanon faced denounced racist reason without, meanwhile occurring in non-reason. That is, it pointed to the collapse of rationality in western rationality or in the White, but not to reason itself:

\begin{abstract}
Black Skin, White Masks is, therefore, like Dante's Inferno, which ends after a seemingly endless journey of witnessing sinful practices of futility with a beautiful ascent that bears witness to the stars, a patently optimistic text despite its motif of failure.The performative contradiction of pessimism is the work itself. Fanon ultimately criticizes the collapse of rationality into Western or White rationality. The text itself-an effort to reason with the reader-is a verdict against irrationalism, although it is not a wholesale endorsement of rationalism. Too much rationalism is, after all, irrational. It is at least unreasonable. (GORDON, 2015, p. 59)
\end{abstract}

The term "new postcolonial humanism" forged by Nissim-Sabat (2011) to describe Lewis Gordon's work, may seem strange from the perspective used in the dichotomy between illuminist reason perspectives, in their assurance of a self-centered subject; and the group of post-structuralist perspectives, in their frontal critique to closed identity and reason notions. From this position, I will remark here on British post-colonial thought ${ }^{20}$. However, it seems that Gordon's philosophical enterprise is precisely the overcoming of this dichotomy, based, at once, on a radical critique of colonialism - seen as part of the modern age and not its antithesis - and on the de-racialization and vindication of rational self-reflection procedures from deviating established, Eurocentric geographies of reason.

\title{
References
}

AGOSTINHO, Santo. Confissões - SANTO AGOSTINHO. Typewriting: Lucia Maria Csernik, $\begin{array}{llll}\text { Canção } & \text { Nova.com. } & 2007 . & \text { Available }\end{array}$ from: https://img.cancaonova.com/noticias/pdf/277537_SantoAgostinho-Confissoes.pdf. Acesso em 20/10/2017

APPIAH, K. A. In my father's house: Africa in the philosophy of culture. New York: Oxford

\footnotetext{
${ }^{20}$ Classifying British post-colonial or diasporic thought as part of a post-structuralist corpus is based on readings of Peters (2000), Bhabha (2004) and Costa (2006).
} 
University Press, 1992.

ARENDT, Hannah. On Violence. New York: Harcourt Brace Jovanovich, 1969.

Asante, M.K. A Filosofia tem sua origem na África: Mito ou Realidade? Blog. Hebreu Negro. dec, Availablefrom http://www.hebreunegro.com.br/2015/12/a-filosofia-tem-suaorigem-na-africa.html. Acesso em 18/11/2017

BHABHA, H. Foreword: Framing Fanon. In: FANON, Frantz. The wretched of the earth. Translated from the French by Richard Philcox with commentary by Jean-Paul Sartre and Homi K Bhabha New York: Grove Press, 2004.

BERNAL, Martin, Black Athena: The Afroasiatic Roots of Classical Civilization (The Fabrication of Ancient Greece 1785-1985, vol. I) New Brunswick: Rutgers University Press, 1987.

. Black Athena Writes Back: Martin Bernal Responds to His Critics. Durham, NC: Duke University Press, 2001.

CHASIN, J. Superação do Liberalismo-literal transcription of classes given during the postgraduation course in Political Philosophy, promoted by the Department of Philosophy and History of the Federal University of Alagoas, between Jan. 25 and Feb. 06 in 1988Available from: <http://ebookbrowse.com/j-chasin-superacao-do-liberalismo-doc- d132585437>. Acesso em 23/08/2010.

COSTA, Sérgio. Desprovincializando a sociologia: a contribuição pós-colonial. Rev. bras. Ci. Soc., São Paulo, v. 21, n. 60, 2006. Available from: $<$ http://www.scielo.br/scielo.php?script=sci_arttext\&pid=S010269092006000100007\&lng=en\&nrm=iso>. Acesso em 5 mar. 2013.

DIOP, C. H. A unidade cultural da África negra: esferas do patriarcado e do matriarcado na antiguidade clássica. Angola: Pedago, 2014. 
DUSSEL, Enrique. 'World-System': Europe as 'Center' and Its 'Periphery' beyond Eurocentrism. In: Beyond Philosophy: Ethics, History, Marxism, and Liberation Theology. Lanham, MD: Rowman \& Littlefield, 2003.

. 'Europe, Modernity, and Eurocentrism. Nepantla, Views from South 1, n. 3, p. 465$78,2000$.

FANON, Frantz. Sociologied'une revolution (Lán V de la revolution algérienne, 1959). Paris: François Maspero, 1968.

Peau noire, masques blacs. Paris: Editions du Seuil, 1952.

Pele negra, máscaras brancas. Salvador: EDUFBA, 2008.

FOE, Nkolo. Afriqueen dialogue, Afriqueen auto-questionnement: universalisme ou provincialisme? "Compromis d'Atlanta" ou initiativehistorique?. Educ. rev., Curitiba, n. 47, p. 175-228, Mar. 2013 . Available from http://www.scielo.br/scielo.php?script=sci_arttext\&pid=S010440602013000100011\&lng=en\&nrm=iso. access on 18 Nov. 2017.

GORDON, L. R. Her Majesty's Other Children: Sketches of Racism from a Neocolonial Age. Lanham, MD: Rowman \& Littlefield, 1997.

Existentia Africana: Understanding Africana existential thought. New York: Routledge, 2000.

- Through the Zone of Nonbeing: A Reading of Black Skin, White Masks in Celebration of Fanon's Eightieth Birthday. The C.L.R. James Journal 11, no. 1 (Summer 2005): $1-43$.

Disciplinary Decadence: Living Thougth in Trying Times. Boulder: Colo.:

Paradigm Publishers, 2006

An Introduction to Africana Philosophy. New York: Cambridge University Press, 2008. 
Decadencia disciplinaria: Pensamiento vivo en tiempos difíciles. Ediciones Abya Yala, Quito, Ecuador, 2013.

. The market colonization of intellectuals. Truth Out, 6 abr. 2010.Disponívelem: <http://www.truthout.org/the-market-colonization-intellectuals58310>.

- Para romper com a teodiceia filosófica. IHU Online - Revista do InstitutoHumanitasUnisinos, Porto Alegre, 17 nov. 2014. Interview given to Andriolli Costa. Available from: $<$ http://www.ihuonline.unisinos.br/index.php?option=com_content\&view=article \&id $=5782 \&$ secao $=459>$.

. What Fanon Said: A Philosophical Introduction to His Life and Thought. New York: Fordham University Press, 2015.

HENRY, Paget. "Africana Phenomenology: Its Philosophical Implications”. Worlds and Knowledges Otherwise 1.3 (2006)

HUSSERL, Edmund. Ideas pertaining to a pure phenomenology and to a phenomenological philosophy.Netherlands: Martinus Nijhoff, 1982.

JUNCOSA, José E. BuenVivir, relacionalidad y disciplina desde el pensamiento de Lewis Gordon y Martin Nakata. Pistas epistémicas decoloniales para laeducación superior. Alteridad, Revista de Educación, n. 9, v. 1, 2014. p. 19-34,

KIERKEGAARD, Søren. Temor e Tremor. In: Os Pensadores. São Paulo: Abril Cultural, 1979. Fear and Trembling and Repetition. Princeton: Princeton University Press, 1983.

KOEPSELL, David R. Breaking Bad e a filosofia. In: ARP, Robert; KOEPSELL, David R. Viver melhor com a química. São Paulo: Figurati, 2014.

MANNONI, Dominique-Octave. Psychologie de lacolonization. Paris: Editions du Seuil, 1950. Prospero and Caliban: The Psychology of Colonization. New York: Praeger, 1964. 
MIGNOLO, Walter. The Darker Side of the Renaissance: Literacy, Territoriality, and Colonization. Ann Arbor, MI: University of Michigan Press, 2003.

NISSIM-SABAT, Marilyn. Radical theory and theory of communication: Lewis Gordon's Phenomenological Critique of the New World Consciousness. Atlantic Journal of Communication, n. 19, p. 28-42, 2011.

MORE, Magobo P. African Philosophy Revisited. Alternation, n. 3, v. 1, p. 109-129, 1996.

OBENGA, Théophile. Ancient Egypt and Black Africa. Chicago, IL: Karnak House, 1992.

OLIVEIRA, Eduardo David de. Cosmovisão africana no Brasil: elementos para uma filosofia afrodescendente. Fortaleza: IBECA, 2003.

PETERS, Michael. Pós-estruturalismo e filosofia da diferença. Coleção Estudos Culturais. v. 6. Belo Horizonte: Autêntica, 2000.

PLANTINGA, Alvin. God, Freedom, and Evil. Michigan: Grand Rapids, MI: William B. Eerdmans Publishing Company, 1974

ROBINSON, Cedric. An Anthropology of Marxism. Aldershot: Ashgate, 2001.

ZILLES, Urbano. Introdução: A fenomenologia husserliana como método radical. In: HUSSERL, Edmund. A crise da humanidade europeia. Porto Alegre, EDIPUCRS. 2012.

SARTRE, J. P. O ser e o nada: ensaio de ontologia fenomenologia. 3. ed. Petrópolis: Vozes, 1997. 